\title{
O 18 BRUMÁRIO, POLÍTICA E PÓS-MODERNISMO
}

\author{
ADRIANO NERVO CODATO
}

Uma das questões centrais da Sociologia Política marxista é a das relações entre "política" e "economia". Como é amplamente conhecido, o trabalho de Marx, O 18 Brumário de Luís Bonaparte, tem sido celebrado como o texto canônico a respeito desse problema teórico e a retomada desse livro, na virada dos anos 1960 para os anos 1970, permitiu ao neomarxismo avançar em muitas direções novas: no desenvolvimento, por exemplo, de uma teoria do Estado contrária ao "instrumentalismo", que rebaixava as complicadas ligações entre as classes economicamente dominantes e o aparelho estatal a uma relação de controle estrito do segundo pelas primeiras; na reformulação de uma teoria da ideologia contrária ao "mecanicismo", que deduzia dos movimentos da economia a configuração e a função das superestruturas culturais; e na compreensão do problema das classes sociais contrária ao "economicismo", que definia as primeiras exclusivamente em função da sua inserção no processo produtivo. Essa manobra intelectual contra a ortodoxia tornou-se mais legítima à medida em que se reconheceu (na verdade, à medida em que não se ignorou mais) a prioridade das questões políticas nas "obras históricas" de Marx. ${ }^{1}$ No que diz respeito ao problema do "Estado" e das suas relações com a "sociedade civil", já em 1960 Maximilien Rubel sugeria que se considerasse o fenômeno do "bonapartismo" - precisamente: a autonomia que o aparelho do Estado francês desfrutava em relação à sociedade

\footnotetext{
${ }^{1}$ As "obras históricas" incluem as análises da política européia da segunda metade do século XIX: A burguesia e a contra-revolução (escrita em 1848), As lutas de classe na França de 1848 a 1850 (1850), Crônicas Inglesas (1852-1854), Lord Palmerston (1853), A Espanha Revolucionária (1854), Herr Vogt (1860), A guerra civil na França (1871), além de O 18 Brumário de Luís Bonaparte (1852).
} 
francesa na segunda metade do XIX - como correspondendo à idéia que Marx fazia do Estado capitalista em geral, e não como um fenômeno político particular. ${ }^{2}$

No final dos anos 1960, menos a aversão ao economicismo reinante e mais uma reação contra o desinteresse sistemático pelas questões relativas ao poder e à política na problemática marxista (de resto o traço básico do "marxismo ocidental"3), foi fundamental para repor o problema do "Estado" numa nova chave interpretativa. Ela deu aos neomarxistas a oportunidade para enfocar o nível jurídico-político (diante do nível econômico), o aparelho do Estado (em relação à "sociedade civil") e a práti ca política (frente à atividade econômica) enquanto objetos de conheci mento distintos. O retorno do Estado à cena intelectual foi provocado também pela tentativa desse marxismo renovado em responder teórica e empiricamente aos desafios postos pelo comportamentalismo da Ciência Política e da Sociologia norte-americanas. Esse movimento "revisionista" acabou por refletir também sobre o mainstream, retirando, de um lado, o assunto do domínio exclusivo dos estudos jurídico-constitucionais e, de outro, enfatizando, a partir de então, a diferença do conceito de "Estado" do de "governo" dos pluralistas. Como recordou Leo Panitch, "Within political science and political sociology, one of the legacies of the new Marxist theory [of the state] was actually that the state was firmly reestablished as part of the conceptual lexicon for the study of contemporary politics". ${ }^{4}$ No que diz respeito à teoria marxista, foi precisamente a partir dessa virada que ela deixou de ser filosofia e crítica da cultura para tornarse novamente "teoria social, teoria sobre a sociedade contemporânea e sobre a política do nosso tempo". 5

Desconfio, contudo, que os trabalhos históricos de Marx que inspiraram o "marxismo como ciência social", para usar a fórmula de Göran Therborn, tenham passado a ser estudados hoje apenas como "textos políticos", à parte ou em contradição com a teoria marxiana no seu conjunto. $\mathrm{O}$ aspecto comum às interpretações politicistas mais contemporâneas d' O 18 Brumário de Luís Bonaparte é, sintomaticamente, a supressão de toda menção à "economia" e a insistência na "especificidade do

2 “'Le bonapartisme, c'est la religion de la bourgeoisie': voilà, mise en boutade par Engels, la pensée fondamentale que Marx a développée dans son Dix-huit Brumaire". Maximilien Rubel, 1960, p. 152.

3 Cf. Perry Anderson, 1976.

${ }^{4}$ Leo Panitch, 2002, p. 92. Para uma visão completa dessa história, v. Bob Jessop, 1990.

${ }^{5}$ Göran Therborn, 1989, p. 390. 
político". Visto que, como enfatizou Theda Skocpol, os neomarxistas nunca abandonaram a perspectiva funcionalista, cujo acordo básico era justamente em torno do papel do Estado na acumulação, reprodução, dominação do capitalismo ${ }^{6}$, essa ausência inesperada repercute em dois campos: nas interpretações "heterodoxas" que se dá do pensamento político de Marx e no tipo de análise política daí resultante "inspirada" nesse marxismo depurado (análise essa que mereceria uma revisão à parte, impossível de ser feita aqui).

A heterodoxia ${ }^{7}$ ganhou novo impulso com a leva de análises que se seguiram às comemorações dos 150 anos de publicação d' $O 18$ Brumário de Luís Bonaparte em 2002. Terrell Carver propôs uma leitura pós-moderna do livro baseada na relação peculiar entre o estilo do texto a linguagem figurativa e a imagética dramática - e a idéia que Marx realmente faria da política: como uma ação simbólica que se dá primariamente no nível emocional ou psicológico, embora tenha efeitos bem concretos. Em termos mais precisos, trata-se do seguinte:

[...] I [...] suggest that rather than stripping away the linguistic extravagance to find the ideas, we reverse the process and find the ideas in the choice of words and imagery. After all, Marx wrote it that way. This strategy displaces the established reading, which is that Marx's text have to be about science, and about historical materialism $[\ldots]$ The most astonishingly original and egregiously underestimated of Marx's devices in the Eighteenth Brumaire is not the idea that people make history albeit under constraints. The novelty is rather the identification of 'circumstances, given and inherited'not with economic conditions or relations of production or any such 'material' feature of experience - but with something quite different: 'tradition from all dead generations'weighing 'like a nightmare on the brain of the living'. 8

6 " [...] at the theoretical level, virtually all neo-Marxists writers on the state have retained deeply embedded society-centered assumptions, not allowing themselves to doubt that, at base, states are inherently shaped by classes or class struggles and function to preserve and expand modes of production". Theda Skocpol, 1985, p. 5.

7 Pelo termo entenda-se: uma denúncia dos constrangimentos estruturais sobre a prática dos agentes políticos, tal como postulado por certas "leis da História", e a recusa da "determinação da política pela economia". As duas somadas equivalem à contestação das visões "científicas" de Marx na chave interpretativa induzida, diz-se, por F. Engels.

8 Terrell Carver, 2002, p. 119 e 120-121. 
James Martin, a partir da suposição segundo a qual haveria n'O 18 Brumário certas premissas que permitiriam entender a política como uma ação performativa, sustentou que a luta política deveria ser concebida, também, como uma disputa sobre "significados", e não apenas como um duelo em torno de interesses materiais: "[...] implicit in what he [Marx] writes is an assumption that political struggle must, at some level, be read in terms of its symbols and imaginary constructions because these are effective elements in making history". 9 Essa nova leitura autorizaria a questionar a centralidade das noções de "classe" e "ideologia" em nome das de "identidade" e "discurso". Tanto a interpretação pós-moderna de Carver quanto a de Martin podem ser vistas como uma continuação (não uma repetição, diga-se) da leitura pósestruturalista d'O 18 Brumário e d'As lutas de classe na França de Jeffrey Mehlman. ${ }^{10}$

Não seria o caso de perguntar se não foi longe demais essa compreensão das relações entre economia, política e ideologia nos comentários a propósito d' $O 18$ Brumário? O objetivo deste artigo é justamente discutir um aspecto relativamente esquecido (ou às vezes explicitamente negado) do livro: o papel do "econômico" diante do "político" e do "ideológico", para falar em jargão.

Meu argumento central é que há nessa série de sete artigos escritos "sob a pressão imediata dos acontecimentos", entre dezembro de 1851 e março de 1852 (18 Br., "Avant-Propos" [1869], p. 434), ${ }^{11}$ uma interpretação da política que é solidária com a concepção materialista da História ${ }^{12}$ e, mais precisamente, com dois princípios teóricos: $(i)$ o lugar de destaque que o "econômico" ocupa no interior dessa concepção e (ii) a cen-

9 James Martin, op. cit., p. 140-141. Para uma crítica às interpretações pós-modernas, v. Norman Geras, 1987, p. 40-84; e Terry Eagleton, 2003.

10 V.Revolution and Repetition: Marx-Hugo-Balzac, 1978. Jeffrey Mehlman propõe que se leia Marx através de Freud. Para uma crítica contundente dessa "desconstrução" de Marx, cf. Margaret A. Rose, v. 2, 1981, p. 79-97.

${ }^{11}$ Para todas as citações literais do texto de Marx adotarei esta notação: $(18 \mathrm{Br}$., p.). Ela corresponde à paginação da tradução francesa do livro, por Maximilien Rubel, a partir da terceira edição (de 1885). Cf. Le 18 Brumaire de Louis Bonaparte. In: Karl Marx, 1994. Vol. IV,Tomo I: Politique. As traduções para o português são minhas.

${ }^{12}$ Para o adjetivo "materialista", v. a carta de K. Marx a L. Kugelmann de 6 mar. 1868: "[Herr Dühring] sabe muito bem que meu método de desenvolvimento não é hegeliano, uma vez que sou materialista e Hegel é idealista". Apenas dizer-se "materialista" não é muito, mas já é um começo. Cf. Karl Marx, 2002, p. 229. 
tralidade da idéia que opõe essência e aparência. Os dois princípios foramnos apresentados no "Prefácio" de 1859 de Para a Crítica da Economia Política.

Nada disso é muito novo, certamente. O próprio Friedrich Engels advertiu que bastaria examinar o trabalho de Marx sobre o golpe de Estado na França para saber que mesmo num texto em que se trata "quase exclusivamente do papel particular desempenhado pelas lutas e acontecimentos políticos", isso se faz, "é claro", nos "limites de sua dependência geral das condições econômicas". ${ }^{13}$ Indagado mais tarde sobre o estatuto do "econômico" no âmbito da teoria social marxiana, Engels enfatizou que o livro de Marx consistiria no melhor "exemplo prático" para pôr à prova dois problemas não triviais da explicação histórica: a relação entre causa e efeito e a relação entre necessidade e acaso. Simplificadamente, o materialismo histórico consistiria em afirmar a irrelevância das narrativas que desprezam as "condições econômicas", assumindo, ao contrário, que "há todo um jogo de ações e reações" entre a superestrutura e a infra-estrutura e que, "em última instância", o econômico acaba sempre por impor-se. ${ }^{14}$ A questão que permanece todavia é: onde exatamente ler essa dinâmica peculiar e complexa entre a base material e a superestrutura (política e ideológica) n'O 18 Brumário?

Pondo de lado as ponderações de Engels, uma sorte de senso comum douto sustentou, e essa é uma opinião renitente, que haveria um "Marx", o historiador político, cujo trabalho seria inventivo, perspicaz e sofisticado; e um outro "Marx", o teórico social, cujo pensamento seria prisioneiro do modelo dualista "base-e-superestrutura" e, por isso, de esquemas de interpretação evolucionistas, mecanicistas e economicistas. Raymond Aron, que achava "as duas brochuras de Marx" - As lutas de classe na França e O 18 Brumário de Luís Bonaparte - "brilhantes", viu a superioridade desses trabalhos na verdade como um desvio: "inspirado pela clarividência de historiador, Marx esquece [sic] suas teorias e analisa os acontecimentos como observador genial". 15

Penso que ler $O 18$ Brumário à luz dessa oposição simplificadora - entre a "teoria" (o modelo) e a "prática" (a análise concreta) - é tresler o

13 Carta de F. Engels a Schmidt, 27 out. 1890. In: Karl Marx e Friedrich Engels, s/d., vol. 3, p. 291, grifos do autor.

14 Carta de F. Engels a Starkenburg, 25 jan. 1894. In: Karl Marx e Friedrich Engels, ibid., p. 298-300.

15 Raymond Aron, 1987, p. 266. 
modelo de análise histórica tal como proposto pelo marxismo clássico no "Prefácio" de 1859. Os escritos "históricos" de Marx sobre a política são, antes de tudo, informados pelas proposições teóricas sistematizadas nos escritos seus "metodológicos", obviedade que se perde de vista quando, sob o pretexto de se refazer o percurso intelectual de Marx, se toma seu pensamento ou em termos estáticos, compartimentando-o em "Filosofia", "Economia", "Política" etc., ou em termos cronológicos, pensando-o como uma evolução. Ironicamente, considerando as datas dos dois livros aqui em questão, e as diferentes avaliações sobre um e outro, trata-se de um caso curioso de involução. Proponho então que se interprete $O 18$ Brumário a partir do "Prefácio" a fim de estabelecer três pontos: (i) o lugar do econômico no texto (o que implica em rever a ortodoxia); (ii) a relação entre o político e o econômico no texto (o que implica em questionar a heterodoxia); e (iii) a natu reza do próprio texto (o que implica em refutar as leituras pós-modernas).

Não me escapa que esse projeto exigiria que se explicitasse como, afinal de contas, pode-se ler o próprio "Prefácio"; ou mesmo como entender o "desenvolvimento" do pensamento de Marx. Esses são todavia problemas que reclamariam um tratamento bem mais extenso. Vou me limitar aqui em indicar algumas "escolhas" que informam minha "política de leitura" do texto marxiano, para falar como T. Carver.

Resumidamente, sabemos que Marx representa o todo social por meio de uma imagem poderosa e polêmica: o conjunto das "relações de produção forma a estrutura econômica da sociedade, a base real sobre a qual se levanta uma superestrutura jurídica e política, e à qual correspondem formas sociais determinadas de consciência". ${ }^{16}$ O que essa passagem, que é na realidade um enunciado teórico, significa?

Em primeiro lugar, atentemos aqui também para a linguagem empregada no texto de 1859. A metáfora "base/superestrutura", que substitui as noções tradicionais "Estado/sociedade civil", indica uma mudança teórica que não encontra, no plano ideal, um nome próprio, isto é, um con ceito. Se ainda é por meio do antigo vocabulário que Marx se expressa nas "obras históricas" - como se recorda: 'em um país como a França, [...] onde o Estado encerra, controla, regula, vigia e mantém sob sua tutela a sociedade civil" (18 Br., p. 477; grifos meus) - seu uso é contudo puramente descritivo ${ }^{17}$ e em grande medida anacrônico. ${ }^{18}$

16 K. Marx, 1982, "Prefácio", p. 25.

17 Cf. Cesare Luporini, 1979, p. 91-102.

${ }^{18}$ Catherine Colliot-Thélène, 1984. 
A figura do "edifício social" a que se recorre não é, entretanto, apenas a expressão de uma carência terminológica ou de um processo arbitrário de substituição de um termo ("Estado"; "sociedade civil") por outro ("superestrutura jurídico-política"; "estrutura econômica da sociedade"). O sentido figurado dessa formulação registra também uma (r)evolução teórica. Ao invés de denotar a oposição entre "Estado" e "sociedade civill, trata-se agora de exprimir duas idéias complementares: (i) a articulação entre as instâncias e (ii) a articulação entre instâncias diferentes (econômica, política e ideológica). Essa distinção, como insistiu Louis Althusser, diz respeito a "diferenças reais, e não apenas [a] diferenças de esferas de atividades, de práticas, de objetos: são diferenças de eficácia". ${ }^{19}$ Assim, o todo social, pensado como uma estrutura formada por níveis específicos, em estreita correlação entre si, é um todo intrincado e desequilibrado. A desproporção entre seus termos vem justamente do fato de que o nível econômico é determinante (Marx), "em última instância" (Engels).

Em que pese a linguagem antiga, tomada de empréstimo da Filosofia Política, já n'O 18 Brumário encontramos em operação essas premissas. Meu objetivo aqui é demonstrar essa operação. Ao invés de contrapor esses dois textos dos anos cinqüenta, pretendo indicar alguns pontos de concordância (o que é diferente, bem entendido, de demonstrar a "aplicação" dos princípios de 1859 na análise de 1852).

$\mathrm{O}$ artigo está dividido em cinco partes. Na primeira procuro ilustrar, de maneira menos esquemática, a interpretação dualista do pensamento de Marx com base no divórcio por ramos de atividade entre o "historiador" e o "teórico social". Na segunda seção apresento minha hipótese de leitura. Ela une a forma (o "estilo") e o conteúdo (a análise do processo social) d'O 18 Brumário aos postulados convencionais do materialismo histórico. Na terceira seção, listo as diferenças entre os textos de 1852 e 1859 e relativizo o desacordo tradicionalmente enfatizado pela maior parte dos comentadores. Na quarta seção busco comprovar um ponto do meu

${ }^{19}$ Louis Althusser, 1978, p. 146. Marx, prossegue Althusser, "também não nos disse que tudo deveria estar contido [nesse edifício], e que tudo fosse ou infra-estrutura ou superestrutura". Id., ibid., p. 146. Terry Eagleton parece sugerir a mesma idéia quando adverte para o uso de um termo como "superestrutura" como um substantivo abstrato, "um 'domínio' dado, fixo de instituições que [a] formam". O fundamental é reter o uso adjetivo do termo. Certas instituições sociais podem, ou não, atuar de maneira "superestrutural". Elas o fazem quando contribuem para a produção/reprodução das relações sociais dominantes. A metáfora não nos diz, então, que o mundo possa ser dividido em "fatias". Terry Eagleton, 1997, p. 81. 
argumento: como se dá, no livro em questão, a "primazia do econômico". E na quinta empenho-me para demonstrar o outro ponto: em que sentido se deve ler, n'O 18 Brumário de Luís Bonaparte, a oposição entre "essência" e "aparência", discutindo, de passagem, o sentido da aparência em política.

\section{TEORIA SOCIAL VERSUS HISTÓRIA}

A partir da pretensa divergência entre o Marx de 1852 e o de 1859 difundiu-se, inclusive no interior do pensamento crítico, a idéia segundo a qual nessa e nas outras "obras históricas" haveria uma interpretação tributária do multideterminismo; nas obras econômicas ou de combate político (o Manifesto Comunista, por exemplo), uma análise prisioneira do unideterminismo. As declarações mais consistentes para sustentar essa dissociação cognitiva do pensamento marxiano viriam, ironicamente, das suas autojustificações teóricas. Tome-se, por exemplo, duas passagens onde Marx pensa o seu próprio ponto de vista: uma retirada do famoso "Prefácio" de 1859 e outra da "Introdução" de 1857 de Para a crí tica da Economia Política.

Sabemos todos que Marx nunca foi contemporâneo do seu desenvolvimento intelectual. Isto é, raras vezes Marx - e Engels - detiveram-se para apresentar os fundamentos teóricos de suas investigações. Há, possivelmente, apenas cinco ou seis momentos em toda obra onde se pode encontrar um discurso sobre o método de análise materialista; ou mais propriamente, uma reflexão sobre a dimensão teórica do materialismo histórico: na Primeira Parte de A Ideologia Alemã (18451846); nas Teses sobre Feuerbach (1845); no referido "Prefácio"; nas anotações sobre economia, não destinadas à publicação, tomadas entre 1857 e 1858, e que vieram à luz somente em 1939 com o título Grundrisse der Kritik der politischen Ökonomie (Rohentwurf), das quais a "Introdução [à Crítica da Economia Política]" constitui parte; no "Posfácio" à segunda edição alemã de $O$ capital (1873); e na correspondência do último Engels (cartas a Bloch e a Schmidt (1890), a Mehring (1893) e a Starkenburg (1894), principalmente).

Na seção 3 da "Introdução" de 1857 (O método da Economia Política) aprende-se, por exemplo, que "o método cientificamente exato" é aquele em que os elementos da economia real (a "população" para ficar no caso escolhido pelo Autor) não são uma abstração, mas uma "rica totalidade de determinações e relações diversas". A realidade social, "o concreto", numa 
palavra, "é a síntese de muitas determinações, isto é, unidade do diverso". ${ }^{20}$ Já no "Prefácio" de 1859, onde Marx conta a que conclusão seus estudos econômicos começados em Paris quinze anos antes haviam chegado, lê-se que "o modo de produção da vida material condiciona o processo em geral de vida social, político e espiritual. Não é a consciência dos homens que determina o seu ser, mas, ao contrário, é o seu ser social que determina sua consciência". ${ }^{21}$

A compreensão literal dessa última passagem (e a sua mera confrontação com a anterior) conduziu os analistas a dois erros simétricos. $\mathrm{O}$ primeiro consistiu em tomar o dito pelo feito. Da apresentação sintética de uma proposição geral sobre a consciência humana (de alcance "ontológico") e de uma advertência específica contra o idealismo alemão, concluiu-se que os estudos posteriores de Marx e dos marxistas deveriam sempre render homenagem à "economia", o princípio explicativo da História. O segundo erro consistiu em tomar o feito pelo dito. Os ensaios sobre a história política da Alemanha, da Inglaterra ou da França, graças ao tema, à linguagem adotada, à sofisticação das explicações apresentadas e à riqueza em detalhes, resultado do trabalho de um historiador minucioso, só poderiam ser entendidos como a concretização da idéia de multideterminação anunciada na "Introdução" de 1857.

E. P. Thompson traduziu essa imaginada ambigüidade do pensamento de Marx em um impasse: haveria ou ortodoxias dispostas a repetir o modelo causal tradicional consagrado na "metáfora mecânica" da base-superestrutura ou simplesmente empirismo; nos dois casos, o que se perderia de vista seria a "dialética da dinâmica social". Como recuperá-la, superando os raciocínios dedutivos (a partir do "modelo") ou indutivos (a partir da "realidade")? Resposta: "Só podemos descrever o processo social - como Marx mostrou em O 18 Brumário - escrevendo história. ${ }^{22}$ Eric Hobsbawm por sua vez afirmou que "o valor principal de Marx para os historiadores" residiria "em suas proposições sobre a história, enquanto distintas de suas proposições sobre a sociedade em geral". ${ }^{23}$

Um comentador resumiu assim o problema central: quando se realiza a revisão das análises de Marx a respeito dos acontecimentos na França entre 1848 e 1851, ressalta o uso de um modelo implícito e ad hoc

${ }^{20}$ K. Marx, 1982, “Introdução", p. 14, grifos meus.

${ }^{21}$ Id., ibid., "Prefácio", p. 25, grifos meus. Na formulação de A Ideologia Alemã: "Não é a consciência que determina a vida, mas a vida que determina a consciência". Karl Marx e Friedrich Engels, L’idéologie allemande. In: Karl Marx. 1982, Vol. III: Philosophie. p. 1057.

22 E. P. Thompson, 2001, p. 158, grifos meus.

${ }^{23}$ Eric Hobsbawn, 1998, p. 162, grifos meus. 
de análise política, ao lado de um modelo teórico mais ou menos explícito que enfatiza certos condicionantes estruturais. Essa tensão entre uma perspectiva que sublinha a autonomia do poder de Estado, a primazia das variáveis estritamente políticas e outra que, na linha da "ortodoxia teórica", trata os eventos revolucionários como manifestações da inexorabilidade do processo histórico, (processo esse governado essencialmente pelas determinações das forças "materiais"), conduziria esse pensamento a uma dificuldade insolúvel. A análise política $a d$ hoc - presente nos famosos textos históricos - resolveria essa contradição e evidenciaria a superioridade do Marx comentarista político sobre o teórico da sociedade. ${ }^{24}$

Como superar essas visões? Como reatar o historiador e o filósofo, o jornalista e o cientista ou: a exposição dos princípios que informam a análise materialista e a análise materialista propriamente dita?

\section{DOIS PRINCÍPIOS EXPLICATIVOS}

A dessemelhança entre um Marx e outro deriva na verdade de certas dificuldades básicas que dizem respeito não exatamente à relação entre os textos de Marx mas às proposições do próprio texto em questão, $O$ 18 Brumário de Luís Bonaparte.

A primeira dificuldade, e a mais superficial, decorre da constatação de um truísmo: a dinâmica dos eventos políticos da II República é independente, na narrativa e, principalmente, na explicação oferecida n' $O$ 18 Brumário, da dinâmica dos eventos econômicos. Em rigor, a crise comercial francesa só comparece como um dos elementos explicativos para o golpe de 2 de dezembro na seção VI do livro (v. 18 Br., p. 517-520), e ainda assim não como o fato mais importante. $O$ fundamental nessa conjuntura é a luta política de classes, ìessa indescritível e ensurdecedora confusão de fusão, revisão, prorrogação, Constituição, conspiração, coalizão, emigração, usurpação e revolução" (18 Br., p. 520 $)^{25}$. Trata-se contudo, do meu ponto de vista, de uma concentração excessiva no argumento

${ }^{24}$ Cf. Martin E. Spencer, 1979, p. 196.

25 Recordemo-nos dos principais elementos dessa conjuntura: tentativa de "golpe de Estado, restabelecimento do sufrágio universal, luta entre o Parlamento e o poder executivo, fronda de orleanisas e legitimistas, conspirações comunistas e revoltas camponesas, ameaças dos republicanos de defender a Constituição de armas nas mãos”. Maximilien Rubel, op. cit., p. 151. 
factual do livro: não é um fato que a economia não causou o golpe de Estado? Disso se conclui que...

A segunda dificuldade reside na leitura demasiado livre de certas partes isoladas de $O 18$ Brumário, onde se enfatiza, de maneira unilateral e num sentido muito vago, a "autonomia da política" sem mesmo atentar para os vários sentidos de "autonomia" presentes no livro ou para a integração dessa noção e o seu significado preciso no conjunto do sistema intelectual marxiano. Penso que seja necessário separar a esse respeito três idéias complementares, mas distintas: (i) a idéia de autonomia (relativa) do político (i. e., do nível jurídico-político em relação ao nível econômico); (ii) a idéia de autonomia (relativa) da política (i. e., da prática política em relação à prática econômica) e (iii) a idéia de autonomia (relativa) do Estado (i. e., do aparelho do Estado em relação à "sociedade civil"). ${ }^{26}$ É usual nas interpretações d' $O$ 18 Brumário de Marx a fusão dessas proposições numa só ou a confusão que resulta ao se tomar uma pela outra quando se pretende enfatizar a "irredutibilidade da política à economia", a "especificidade do político" etc. Trata-se, portanto, de desatenção ao argumento conceitual do livro.

A terceira dificuldade, que é uma espécie de exagero da segunda, e portanto mais questionável, reside na desconsideração da obra de Marx como um "sistema intelectual" que dispõe (certa ou errada, não importa) de uma "teoria do desenvolvimento histórico". 27 Um sistema que certamente comporta correções de rumo, torções de sentido em certos conceitos e deslizes terminológicos - e mesmo a oposição entre problemáticas teóricas distintas. ${ }^{28}$ Mas um sistema porque conserva um princípio geral ou um "fio condutor", para retomar a notória expressão do "Prefácio" de 1859: a primazia do econômico. Essa é a primeira lição da concepção materialista da História. A segunda lição, igualmente central nessa concepção, é a separação, postulada inicialmente em A Ideologia Alemã, entre essência (a vida material) e aparência (a vida "espiritual"). Essa diferença foi traduzida em 1859 em termos bastante simples:

Assim como não se julga o que um indivíduo é a partir do julgamento que ele faz de si mesmo, da mesma maneira não se

26 A inspiração aqui é Nicos Poulantzas, 1968, passim.

27 Perry Anderson, 1984, p. 100.

28 Para a "evolução", cf. István Mészáros, 1979, capítulo VIII; para as "torções de sentido", cf. Claude Lefort, 1990; para a separação das "problemáticas", cf. Louis Althusser, 1965. 
pode julgar uma época de transformação a partir de sua própria consciência; ao contrário, é preciso explicar essa consciência a partir das contradições da vida material [...].29

Mesmo um exame pouco atencioso do "Prefácio" de Para a crítica da Economia Política constatará a centralidade desses dois princípios explicativos do materialismo de Marx. ${ }^{30}$

Em que sentido então se poderia aliar a interpretação da vida política francesa de meados do século XIX (precisamente: a análise minuciosa dos acontecimentos de 24 de fevereiro de 1848 a 2 de dezembro de 1851), exposta em detalhe n'O 18 Brumário de Luís Bonaparte, às instruções gerais para a análise da sociedade em geral resumida, exatos sete anos depois, no "Prefácio" de 1859? O que equivale dizer: qual o peso da concepção materialista da História na análise concreta da política pelo marxismo clássico? ${ }^{31}$

Minha sugestão é que se verifique o efeito dessas duas proposições fundamentais - a "primazia do econômico" e a oposição entre "essência e aparência" - na escritura d'O 18 Brumário em dois níveis: sobre a sua forma e sobre o seu conteúdo. O primeiro nível - a forma de expressão - diz respeito à lógica que preside a argumentação (e não ao "estilo" exuberante do texto, embora não seja indiferente a ele). Ela é tributária principalmente da segunda proposição. O segundo nível - o conteúdo - diz respeito à análise do processo político concreto (e não a um princípio teórico abstrato). Ela é tributária principalmente da primeira proposição.

Este comentário de texto será feito portanto a partir dessa grade interpretativa.

\section{OS DISCURSOS E SEUS TIPOS}

Há, nessa hipótese de leitura, uma série de impedimentos bem conhecidos que deveriam travar a inspeção, a aproximação e a superposição dos dois trabalhos, em quase tudo desiguais. Recordemos aqui as in-

29 Karl Marx, 1982, "Prefácio", p. 25-26.

30 Terrell Carver 1983 precisamente esse ponto: "Why should readers really need a 'guiding thread'?".

${ }^{31}$ Há um trabalho recente que fez essa aproximação, mas num sentido bem diferente do proposto aqui. Cf. Jonathan Wolff, 2002. 
terpretações mais tradicionais. Elas enfatizam quatro divergências irreconciliáveis.

Afirma-se que enquanto $O 18$ Brumário de Luís Bonaparte é, reconhecidamente, uma análise de conjuntura destinada a explicar um evento político discreto - o golpe de um "aventureiro" (18 Br., p. 439) -, o "Prefácio" de Para a crítica da Economia Política é o resumo de uma teoria geral da História, onde o que conta são as transformações da estrutura social através das "épocas progressivas da formação econômica da sociedade, [isto é] os modos de produção":32 ora, diferença de níveis de abstração, em primeiro lugar.

Entretanto, essa separação entre um texto "teórico" (mais "abstrato") e outro "histórico" (mais "concreto") não é a maior dificuldade. É preciso frisar que, segundo a compreensão usual, enquanto o "Prefácio" postularia uma necessidade férrea e absoluta, conforme a ação de determinadas "leis" que permitiriam inclusive anunciar o futuro da humanidade, $O 18 \mathrm{Bru}$ mário seria o mais bem acabado exemplo da atuação da contingência na História: diferença de modelos de interpretação, em segundo lugar.

No "Prefácio", a base econômica não é só o fundamento das práticas políticas, ideológicas etc., mas a sua causa: "O modo de produção da vida material condiciona o processo em geral da vida social, política e espiritual". ${ }^{33}$ Existe aqui um postulado impossível de ignorar. Ora, nada mais distante das interpretações avançadas n'O 18 Brumário. É evidente, para quem lê o livro, que se está muito distante dessa posição "mecanicista". As motivações das ações humanas são muito mais complexas e dificilmente podem ser reduzidas a manifestações de uma única causa fundamental. $\mathrm{O}$ que separava os legitimistas dos orleanistas? Certamente o fato de os primeiros representarem o capital financeiro e industrial; e os segundos, a grande propriedade fundiária. Contudo, sustenta Marx, não apenas: "Que ao mesmo tempo velhas recordações, inimizades pessoais, esperanças e temores, preconceitos e ilusões, simpatias e antipatias, convicções, questões de fé e de princípio os tenham ligado à uma ou à outra casa real, quem sonharia em negá-lo?" (18 Br., p. 464). Diferença de tipos de causação, em terceiro lugar.

Por fim, enquanto a categoria "luta de classes" é onipresente n'O 18 Brumário, ela não só está ausente no "Prefácio", como é efeti- 
vamente substituída por outra - a contradição entre "as forças produtivas materiais da sociedade" e "as relações de produção existentes". ${ }^{34}$ Haveria, portanto, a partir daí, duas variáveis independentes no marxismo (para falar na linguagem formalizada da Ciência) dificilmente reconciliáveis: enquanto n'O 18 Brumário o princípio de análise da evolução política é a "luta de classes", no "Prefácio" de 1859 a contradição na "base econômica" 35 entre forças produtivas e relações de produção parece funcionar como o modelo de explanação da transformação histórica. Diferença de princípios de explicação, em quarto lugar.

Essas são, sem dúvida, diferenças importantes. Mas não são incompatibilidades lógicas. Em primeiro lugar porque essas diferenças decorrem exatamente do tipo de discurso e não da natureza do argumento. E o tipo do discurso decorre, por sua vez, do propósito dos dois textos. Ou mais exatamente: do objeto teórico de cada trabalho. Como aliás recordou Terry Eagleton:

Talvez os pós-modernistas temam que uma atenção para as grandes narrativas vão reduzir as pequenas narrativas a meros efeitos delas; mas é difícil ver que o Brumário simplesmente 'expulsa' o estado da luta de classes francesa da natureza da produção capitalista em geral. Para Marx, pelo menos, o objetivo da análise [nesse caso] não era o geral mas o concreto; ele apenas reconhecia, junto com Hegel e qualquer pensador sério, a impossibilidade de construir o concreto sem categorias gerais. ${ }^{36}$

Ora, se um deles é o esboço de uma visão totalizante sobre a história universal, enquanto o outro abrange apenas quatro anos críticos da política francesa na metade do século XIX, então "não é surpresa que haja um repertório conceitual diferente apropriado para os dois casos". ${ }^{37}$ Assim, por que não pensar que a proposição (ontológica) mais abstrata ("Não é a consciência do homem que determina o seu ser, mas, ao contrário, é o seu ser social que determina a sua consciência") informa - em termos mais precisos, isto é, como condição ou como influência - o exame do processo histórico mais concreto? Por que não ponderar que o oposto de "con-

34 Id., ibid., p. 25.

35 Id., ibid., p. 25.

36 Terry Eagleton, 1998, p. 56.

37 Jonathan Wolff, op. cit., p. 2. 
tingência" (supondo que $O 18$ Brumário seja a crônica de uma eventualidade) ${ }^{38}$ não é "necessidade" (supondo igualmente que o "Prefácio" de 1859 seja a postulação de um percurso inevitável e pré-determinado da História) ${ }^{39}$, mas possibilidades limitadas de converter interesses em práticas? Por que não dispor, sob uma hierarquia mais complexa, ao invés de contrapor, as motivações econômicas a todas as outras classes de motivações não-econômicas que determinam a ação política segundo um princípio mais exigente e mais preciso (supondo, é claro, que todo problema da causação se dê em torno de "motivos")? Por que não pensar, enfim, que a luta de classes é inexplicável sem referência às classes, e que as classes simplesmente não existem fora das (ou anteriormente às) relações de produção? Não é propriamente um segredo que "para Marx as classes são [...] um aspecto das relações de produção. [...] As classes derivam da posição em que os vários grupos de indivíduos se encontram frente à propriedade privada dos meios de produção". 40

Assim posto, não penso que os dois textos se completem (no sentido mais convencional: um "teórico", outro "empírico") ou se confundam (no sentido mais artificial: tornem-se indistintos) mas sim que, postos um diante do outro, indiquem uma via que permita romper com o vício habitual do modo de leitura dos mais variados intérpretes - ou politicismo (na sua versão "heterodoxa"), ou economicismo (na sua versão "ortodoxa"), e mais recentemente, na falta de um nome melhor, idealismo (na sua versão "pós-moderna").

\section{A PRIMAZIA DO ECONÔMICO}

Mencionei acima a centralidade do "econômico" na argumentação marxiana. Mas o que se deve entender por "primazia do econômico"? E como essa prioridade entre todas as outras vem expressa num livro cujo tema principal é, afinal de contas, uma questão política? De maneira idên-

38 O que é difícil de sustentar, visto que «o golpe de Estado [...] foi um resultado necessário e inevitável da evolução [dos acontecimentos] anteriores» (18 Br., p. 521).

39 A esse respeito v. a refutação enfática ao "etapismo" na carta de Marx a Vera Zasoulich, de março de 1881.

40 Anthony Giddens, 1984, p. 72, grifos meus. Raymond Aron também concorda que na famosa passagem do "Prefácio" de 1859 "nem a noção de classes nem o conceito de luta de classes aparecem aí explicitamente. No entanto, é fácil reintroduzi-los nessa concepção geral”. Para essa operação, v. op. cit., p. 140-141. 
tica: como se deve entender a oposição postulada entre "essência" e "aparência"? Onde (e como) se poderia encontrá-la n'O 18 Brumário de Luís Bonaparte?

A "primazia do econômico" é um postulado controverso e, como lembrou Engels, de difícil verificação empírica. Ele só surge na análise retrospectivamente e a exposição da conexão entre a "série de acontecimentos da história do dia-a-dia" (os eventos) nem sempre permite ao observador recuar até as "causas em última instância econômicas" 41 - pois essas são causas que atuam "inconscientemente e involuntariamente" 42 (no nível, portanto, das estruturas). Logo, esse não é um princípio auto-evidente, para o analista, ou consciente, para o agente.

A segunda restrição que se deve fazer ao entendimento dessa idéia é que "o fato econômico" não é "o único fato determinante". Ao referir-se precisamente a essa questão, Engels enfatizou, contra seus críticos, que o esquema explicativo do marxismo clássico aplicado à análise de "uma época histórica" deveria sempre considerar o "jogo recíproco de ações e reações" entre "o aspecto econômico" e os "demais fatores", sendo "O 18 Brumário de Luís Bonaparte, em particular, um exemplo magnífico de aplicação" dessa relação complexa de causalidade. Há na verdade uma série de "condições políticas e mesmo a tradição, que perambula como um duende no cérebro dos homens", é preciso notar, "também exercem sua influência sobre o curso das lutas históricas e, em muitos casos, determinam sua forma, como fator predominante". ${ }^{43} \mathrm{O}$ modelo de causalidade histórica exposto no "Prefácio" de 1859 seria portanto parcial (i. e., não representativo do pensamento completo dos autores) e essa parcialidade resultaria de sua formulação antitética: "face aos adversários, éramos forçados a sublinhar este princípio primordial que eles negavam [...]"’4 a todo custo nas narrativas tradicionais.

A interpretação de Engels, todavia, e as duas idéias básicas que ela contém - "sobredeterminação" e "determinação em última instância", na linguagem althusseriana - mesmo que fosse válida para a compreensão das transformações históricas em geral, não resolveria a questão da interpretação da segunda edição do "18 Brumário" (o golpe de Estado) à luz dos

\footnotetext{
41 “Introdução de Friedrich Engels à edição de 1895”. In: Karl Marx, 1982, p. 189.

42 Carta de F. Engels a Bloch, 21-22 set. 1890. In: Karl Marx e Friedrich Engels, op. cit., p. 285.

43 Todas as expressões entre aspas são de Engels, ibid., p. 284-286; grifos do autor.

${ }^{44}$ Id., ibid., p. 286.
} 
princípios materialistas expostos no "Prefácio". E o recuo tático de Engels frente a seus críticos soa antes como uma desculpa que uma razão.

Se a primeira idéia (baseada num "conjunto inumerável de forças que se entrecruzam”) é, de fato, a idéia-força do livro ou, por outra, o livro é a ilustração exemplar desse princípio, a segunda, baseada nas "circunstâncias econômicas", 45 não integra, ou ao menos não assim, seu esquema explicativo. Para que o golpe de Estado fosse explicável, em última instância, pela "economia", o papel que Marx atribui à "pequena crise comercial" (18 Br., p. 517) de 1851 deveria ser exagerado. De fato, nem mesmo se poderia afirmar que a economia (no sentido mais trivial: como prática econômica ou como motivo econômico da ação) cumpriu um papel nas lutas entre a burguesia no Parlamento e a burguesia fora do parlamento. É o que o próprio Marx indica:

Quando os negócios prosperavam, como era o caso ainda em princípios de 1851, a burguesia comercial enfurecia-se contra toda luta parlamentar, para que o comércio não perdesse sua intensidade. Quando os negócios diminuíam, como foi constantemente o caso a partir do fim de fevereiro de 1851, ela atribuía a estagnação às lutas parlamentares e clamava pelo seu fim para permitir ao comércio retomar seu ritmo (18 Br., p. 515).

Essa "circunstância econômica" - a crise geral do comércio - é, na verdade, mais um dos fatores que compõe o quadro geral desse período e que conduz a burguesia francesa a abdicar de seu "poder político" em nome de seus "interesses de classe" (18 Br., p. 514). Ela aprendeu no final das contas que, no curso das lutas políticas, "para salvar sua bolsa seria preciso perder a coroa" (18 Br., p. 482). Examine essa passagem:

Imagine-se agora o burguês francês: a que ponto, em meio a esse pânico comercial, seu espírito mercantil é torturado, atormentado, aturdido pelos rumores de golpes de Estado e de restauração do sufrágio universal, pela luta entre o Parlamento e o Poder Executivo, pela fronda [guerra civil] entre orleanistas e legitimistas, pelas conspirações comunistas no sul do país, pelas supostas jacqueries nos Departamentos de Nièvre e Cher, pela propaganda de diversos candidatos à presidência, pelas palavras de ordem inconseqüentes dos jornais, pelas ameaças dos republicanos de 
defender a Constituição e o sufrágio universal de armas na mão, pela pregação dos heróis emigrados in partibus, que anunciavam o fim do mundo no segundo domingo de maio de 1852, pense-se em tudo isso e se compreenderá que, em meio a essa indescritível e ensurdecedora confusão de fusão, revisão, prorrogação, Constituição, conspiração, coalizão, emigração, usurpação e revolução, o burguês, espumando de raiva, lança à sua república parlamentar este grito: 'Antes um fim com terror, do que um terror sem fim' ( 18 $B r .$, p. 519-520).

A conclusão dessa comédia contém no entanto uma lição: ainda que a "economia" não comande absolutamente o comportamento das classes, o interesse puramente político de classe submete-se, estrategicamente, ao interesse econômico geral de classe - o capitalismo, como regime de exploração econômica e como regime de dominação política. Nessa conjuntura precisa, a burguesia, como classe, "reconhece" (ainda que essa não seja uma ação nem consciente nem "racional") que para manter intacto seu poder social, é necessário quebrar seu poder político; que o burguês particular só pode continuar a explorar as outras classes e a desfrutar tranqüilamente a propriedade, a família, a religião e a ordem sob a condição de que sua classe seja condenada, como as outras, à mesma nulidade política ( $18 \mathrm{Br}$., p. 481-482; grifos meus).

O "econômico" tem portanto de ser tomado, nesse contexto, como o princípio base de organização da vida social que não deve ser contornado nem pode ser negado. Assim, "o econômico" não se confunde com "a economia" (no sentido de atividade econômica vulgar, como prática econômica ou como acontecimentos econômicos) e a "primazia do econômico" refere-se ao papel determinante das estruturas econômicas, e não a uma relação de causação simples entre razões econômicas estritas ("motivações") e condutas políticas empiricamente verificáveis (“ações”).

O lugar e a função que os camponeses parcelares, "a massa do povo francês" (18 Br., p. 532), ocupam na argumentação de Marx são paradigmáticos dessa idéia.

Como e porquê Bonaparte (o sobrinho) pôde tornar-se o representante político dessa massa - e, notadamente, a forma que essa representação assumiu: ao mesmo tempo como seu "senhor" e como seu "protetor" (18 $B r .$, p. 533) - só são explicáveis em função das transformações nas relações de produção capitalistas na França entre fins do século XVIII e meados do século XIX. De maneira idêntica, a nova forma do "Estado moderno" - centralizado, 
“forte e absoluto" (18 Br., p. 537) - só é explicável em função da ruína progressiva da pequena propriedade, justamente a primeira das "idées napoléniennes" (18 Br., p. 535; em francês no original) denotada por Marx.

Depois que a primeira Revolução [1789-1799] transformara os camponeses semi-servos em livres proprietários de terra, Napoleão [o tio] consolidou e regulamentou as condições sob as quais eles podiam tranqüilamente explorar o solo da França que acabava de lhes caber e satisfazer seu desejo juvenil de propriedade. Mas o que agora provoca a ruína do camponês francês é precisamente sua pequena propriedade, a divisão da terra, a forma de propriedade que Napoleão consolidou na França. Essas foram exatamente as condições materiais que fizeram do camponês francês um pequeno proprietário e de Napoleão um imperador. Duas gerações foram suficientes para produzir esse resultado inevitável: deterioração progressiva da agricultura, endividamento progressivo do agricultor. A forma 'napoleônica' da propriedade, que foi no princípio do século XIX a condição para libertação e enriquecimento do campesinato francês, tornou-se, durante esse século, a lei da sua escravização e pauperização ( $18 \mathrm{Br}$., p. 535, grifos meus).

Nem é preciso ler nas entrelinhas. As condições materiais de existência do pequeno proprietário, essa "ordre matériel" (18 Br., p. 537; em francês no original) peculiar que constitui o fundamento objetivo da sua prática política e das suas representações ideológicas, impõe a ele um isolamento embrutecedor que impede não apenas que o campesinato se constitua como classe, mas principalmente que ele se represente de forma autônoma "no Parlamento" (18 Br., p. 533). A escravização da pequena propriedade ao capital, que dela extrai, como um "vampiro", através de hipotecas, "lucros, juros e renda", e que "transformou a massa da nação francesa em trogloditas" (18 Br., p. 536), em uma massa de miseráveis; os impostos que pesam sobre a pequena propriedade e "engendram uma superpopulação desocupada" cuja forma de sobrevivência são os empregos públicos (uma espécie de "esmola respeitável") que incham o Estado (18 Br., p. 537): essas são as condições - econômicas - que formarão o lumpemproletariado de Paris e são esses que servirão de verdadeiro apoio ao "Bonaparte sans phrase" (18 Br., p. 489). 
A legitimidade política que os camponeses emprestam ao Estado bonapartista é contudo trocada por uma ilusão ideológica. A nostalgia do Império e de suas "glórias" - i. e., a consagração da propriedade da terra - projetaram diante dos camponeses franceses a miragem segundo a qual "um homem chamado Napoleão" (18 Br., p. 533) seria capaz de realizar o milagre de deter a História. Sua identificação com o segundo Bonaparte vem justamente daí: da idéia que um poder executivo forte seria o meio de preservá-los do desenvolvimento do capitalismo. Ironicamente, justo o que o II Império tratou, nos vinte anos seguintes, de assegurar.

Segundo Marx,

O [II] Império foi aclamado de um extremo a outro do mundo como o salvador da sociedade. Sob sua égide, a sociedade burguesa, livre de preocupações políticas, atingiu um desenvolvimento que nem ela mesma esperava. Sua indústria e seu comércio adquiriram proporções gigantescas; a especulação financeira realizou orgias cosmopolitas. ${ }^{46}$

Todas as contas feitas, o "bonapartismo", enquanto realidade histórica, ou mais exatamente, as condições materiais que tornaram seu advento possível, só são inteligíveis a partir da caracterização precisa da estrutura econômica da sociedade francesa num estágio determinado do seu desenvolvimento - isto é, só são inteligíveis a partir do "econômico".

Olhado mais de perto, o "econômico" não pode portanto ser entendido, nos estudos políticos de Marx (O 18 Brumário de Luís Bona parte aí incluído), como o "contexto social" em geral - o enquadramento - das práticas de classe, as suas circunstâncias, o pano de fundo onde a evolução da II República se dá. A sugestão de Fred Block para pensar em termos mais exatos a "especificidade do político" e, nesse sentido, a diferença entre o poder "do Estado" (da burocracia) diante do poder "da classe" (dominante), assim como o grau, maior ou menor, de independência dos state managers como o resultado contingente do "contexto de classe" em que esse poder é exercido, pode até se constituir numa 
alternativa à noção pouco operacional de "autonomia relativa de Estado" proposta por Nicos Poulantzas, mas está longe de ajustar-se à noção marxiana de "estrutura econômica". ${ }^{47}$

Penso que o "econômico" é mais exatamente: $(i)$ o "interesse geral" da classe burguesa - o ordenamento capitalista - que deve ser garantido sempre, mesmo quando a burguesia "perdeu sua vocação para governar" (18 Br., p. 500); (ii) a "variável" que em última instância determina - o condicionamento, portanto - as ações políticas, as representações ideológicas etc. dos agentes sociais e (iii) a "realidade última" - o fundamento - dos conflitos políticos entre as classes. ${ }^{48}$

Portanto, se cada facção da monarquia desejava impor, contra a outra, a restauração de sua própria dinastia, isto significava unicamente que cada um dos dois grandes interesses em que se divide a burguesia - propriedade fundiária e capital - procurava restaurar sua própria supremacia e subordinar o outro ( $18 \mathrm{Br}$., p. 465; grifos do autor).

No prefácio à terceira edição alemã de 1885 de $O 18$ Brumário, Engels, sublinhando a importância do autor e da obra, advertiu:

Fora precisamente Marx quem primeiro descobrira a grande le $i$ da marcha da História, a lei segundo a qual todas as lutas históricas quer se processem no domínio político, religioso, filosófico ou qualquer outro campo ideológico, são na realidade apenas a expressão mais ou menos clara de lutas entre classes sociais, e que a existência e, portanto, também os conflitos entre essas classes são, por seu turno, condicionados pelo grau de desenvolvimento de sua situação econômica, pelo seu modo de produção e pelo seu modo de troca, este determinado pelo precedente. Essa lei - que tem para a História a mesma importância que a lei da transformação da energia tem para as

47 O que não seria problema algum se Block não confundisse "contexto de classe" com "o papel determinante das relações de produção". Nos seus próprios termos: "[...] the exercise of state power occurs within particular class contexts, which shape and limit the exercise of that power. These class contexts in turn arte the products of particular relations of production". Fred Block, 1987, p. 84. 48 Note bem: não se trata de aspectos diferentes da mesma realidade, ou funções complementares da "estrutura econômica", mas de três faces da mesma idéia vistas por três ângulos diferentes. 
ciências naturais - forneceu-lhe, aqui também, a chave para a compreensão da história da II República Francesa. ${ }^{49}$

Descontado o cientificismo dessa proposição, o resumo acima fixa o princípio teórico que explica não somente os fenômenos políticos franceses de 1848 a 1851, mas os fenômenos políticos.

Esquematicamente: a centralidade de toda a explanação está ancorada na noção de luta de classes e essa contradição entre as classes não deriva de uma oposição qualquer, mas das suas "situações econômicas" respectivas (ainda que elas possam assumir "formas" específicas: jurídicas, políticas, ideológicas, simbólicas etc.). As análises históricas de Marx não negam essa realidade, não contornam essa tese, nem propõem outro princípio teórico diante da "primazia do econômico", assim entendido. O que $O 18$ Brumário evidencia, por seu turno, é a dissimulação desse fato na política, seja porque a atividade política (os grupos puramente políticos, a representação partidária das classes e frações de classe etc.) nem sempre pode ser ligada explicitamente aos interesses econômicos, seja porque essa dissimulação do que é em relação ao que parece ser é o que torna a dominação "legítima".

Recorde-se, para o primeiro ponto, a ação desastrada da Montagne - a pequena-burguesia democrática - no 13 de junho em defesa da "Constituição" (18 Br., p. 468-469). Da mesma maneira, recorde-se que os representantes dos interesses de uma classe nem sempre precisam ser idênticos a ela ou nela recrutados: "Não se deve [...] imaginar que os representantes democratas [a Montagne] sejam todos shopkeepers, lojistas, ou simpatizantes destes últimos. Graças à sua educação e situação individual, podem ser tão diferentes uns dos outros como o dia e a noite" (18 $B r .$, p. 467).

Há aqui em ação um jogo entre essência e aparência que preside e estrutura a argumentação. Exagerando um pouco, talvez se pudesse mesmo pensar que essa dissimulação do que é e do que se vê é a possibilidade mesma da vida política: Napoleão III deveria apresentar-se à vista de todos como o procurador estrito da aristocracia financeira ou, antes, como o mandatário do campesinato?

49 "Prefácio de Engels para a terceira edição alemã” [1885]. In: Karl Marx, 1978, p. 327-328, grifos meus. 


\section{APARÊNCIA E ESSÊNCIA}

A segunda proposição central da concepção materialista da História é aquela que diz respeito ao antagonismo entre essência e aparência, na linguagem excessivamente filosófica de A Ideologia Alemã. Ela está presente, como já se mencionou, no "Prefácio" de 1859 ("Assim como não se julga o que um indivíduo é a partir do julgamento que ele faz de si mesmo" etc.) e Marx irá antecipar literalmente essa mesma formulação em 1852 na seção III d'O 18 Brumário:

E assim como na vida privada distingue-se o que um homem pensa e diz de si mesmo daquilo que ele é e faz na realidade, convém igualmente, nas lutas históricas, distinguir ainda mais a retórica e as fantasias dos partidos, de um lado, de sua verdadeira natureza e de seus verdadeiros interesses, de outro, distinguir o que eles imaginam ser daquilo que eles realmente são" (18 Br., p. 465; grifos meus).

Para Claude Lefort, a realização desse princípio, a diferença entre essência e aparência, decorre, quando se examina a obra, da intenção do autor e do método empregado. A intenção desmistificadora que constitui, de resto, o grande objetivo anunciado do trabalho, ${ }^{50}$ resulta no estilo adotado pelo livro e o estilo do texto, eu poderia acrescentar, submete-se à lógica da argumentação, já que não é um expediente puramente formal. Os pós-modernos têm razão em enfatizar os méritos do caráter alegórico da linguagem empregada por Marx no livro (a série infindável de metáforas, metonímias, lítotes, sinédoques, hipérboles, oximoros etc.) e em censurar a desimportância que Engels atribui, no Prefácio de 1885, a esse recurso literário (tratar-se-ia apenas de "uma exposição concisa [e] epigramática" da história política francesa). Mas me parece excessivo hipostasiar a linguagem do texto. LaCapra defendeu um ponto de vista no mínimo curioso: depois de derrotados o proletariado de Paris, a pequena-burguesia democrática, a burguesia republicana e o partido da ordem, nessa ordem, como se recorda, "the one social force that is not beaten by the course of events

50 A comparação que o próprio Marx faz da sua explicação para o golpe de 2 de dezembro com as duas interpretações rivais (de Victor Hugo, Napoleón, le Petit (Londres, 1852) e de P.J. Proudhon, La Révolution sociale démontrée par lê coup d'Etat du 2 décembre (Paris, 1852) dá bem a medida do que se quer dizer. Cf. 18 Br., "Avant-Propos", 1869, p. 433. 
as analyzed by Marx is the force of language as Marx himself uses it". O argumento inteiro é o seguinte:

The almost Rabelaisian exuberance of Marx's writing is, however, itself a force that cannot be contained within one-sided interpretations. [...] in a work such as The Eighteenth Brumaire, Marx deploys a powerfully canivalized style - one that exceeds any narrowly productive or didactic project or goal. Through this use of language, Marx confronts a world in which the critic, despite the desire of full mastery, is never altogether immune from mystification - hence the necessity for antidotes (such as parody) whose effectiveness is never certain. ${ }^{51}$

No sentido oposto, penso que encontramos n'O 18 Brumário de Marx um gênero literário em que a forma (o "estilo") está a serviço do conteúdo (a análise materialista do processo social) e não o contrário. Se as interpretações pós-modernas possuem a virtude de reprovar o modo tradicional ("ortodoxo") de leitura dos textos de Marx, caem no mesmo pecado ao propor uma "política de leitura" absolutamente convencional do "Prefácio" de 1859. Ao se fixarem nos seus enunciados explícitos dispensam a verificação da validade dos conceitos. Daí que as assertivas aqui em questão terminam, nessa chave interpretativa, por ficar ocultas graças aos "efeitos especiais" produzidos pela linguagem do livro. ${ }^{52}$

Retomando o argumento: a própria escritura do texto trás em si, no andamento da exposição, o movimento (dialético?) entre aparência e essência. Como Lefort sugeriu, a operação realizada por Marx é no fundo a da

[...] arte da desmistificação no exame das peripécias da intriga política - [trata-se da] arte do analista virtuoso que consegue fazer com que o palco gire para mostrar o avesso do cenário; uma mesma ironia ao desvelar a comédia por trás da tragédia da História; ao reduzir os supostos heróis à dimensão de sua

51 Dominick LaCapra, 1987, p. 289 e 288 respectivamente. A conclusão de LaCapra é a seguinte: "He [Marx] simultaneously raises for us the relationship, in a historical account, between cognitive (or 'scientific') and performative uses of language - prominently including carnivalesque uses" (id., ibid., p. 289-290).

52 "Actually those especial effects were the closest Marx could get to the movies". Terrell Carver, op. cit., p. 119. 
mediocridade, ao dissolver no pântano dos interesses a mixórdia das ideologias, mostrando, simultaneamente, os sinais da inelutável gestação de um novo mundo. ${ }^{53}$

O método empregado por Marx consiste assim na habilidade para discernir, sob as aparências, as razões efetivas de tão "gritantes antinomias" que caracterizam essa época, confundem os contemporâneos e desconcertam os analistas:

constitucionalistas que conspiram abertamente contra a Constituição; revolucionários que se confessam constitucionalistas; uma Assembléia nacional que pretende ser todo-poderosa mas que permanece sempre parlamentar; uma Montagne que faz da resignação sua vocação e que consola-se diante de suas derrotas presentes profetizando vitórias futuras; realistas que são os patres conscripti da república (18 Br., p. 461).

Apesar desses disfarces caricatos, esse mundo ilusório da política (mas ao mesmo tempo "real", pois é assim que as coisas aparecem e é assim que as coisas acontecem) não detém o empenho de Marx "em descobrir [...] o sentido das práticas nas quais as instituições e as representações se fundamentam, em captar o princípio de sua gênese" ${ }^{54}$. Afinal, todos aprendemos que orleanistas e legitimistas defendiam seus interesses, o domínio da burguesia, como "partido da ordem", essencialmente um "rótulo social e não [meramente] político", como lembrou o próprio Marx (18 Br., p. 465). Não seria falso concluir, a partir do exemplo dos realistas coligados, que o fundamento último desse mundo não são interesses quaisquer, mas os interesses econômicos de classe. Reencontramos dessa maneira a "essência". Acompanhe-se mais atentamente essa longa e bem conhecida passagem. Ela condensa e exprime ao mesmo tempo os dois princípios que quero enfatizar:

Quando se examina a situação mais de perto, esta aparência superficial que dissimula a luta de classes e a fisionomia peculiar desse período [i. e., o período da "república cons-

53 Claude Lefort, 1991.

54 Claude Lefort, id., p. 179. 
titucional"] desaparece [...]. Legitimistas e orleanistas constituíam [...] as duas grandes frações do partido da ordem [...]. Sob os Bourbons fora a grande propriedade agrária que havia reinado, com seus padres e seus lacaios, sob os Orléans fora a alta finança, a grande indústria, o grande comércio, isto é, o capital, com seus advogados, professores e oradores bemfalantes. [...] O que separava essas duas frações não era nenhum dos pretensos princípios, eram suas condições materiais de existência, dois tipos diferentes de propriedade, era a velha oposição entre a cidade e o campo, a rivalidade entre o capital e a propriedade da terra. [...] Enquanto orleanistas e legitimistas, enquanto cada uma dessas frações procurava persuadir-se e persuadir seu adversário que apenas suas ligações às duas dinastias as separava, os fatos provaram mais tarde que fora principalmente seus interesses opostos que haviam impedido a união das duas dinastias ( $18 \mathrm{Br}$., p. 464-465, grifos do autor).

Todo comentário aqui seria supérfluo. Trata-se de uma operação analítica que implica duas reduções: as (auto)representações ideológicas são reduzidas ao seu fundamento de classe - orleanistas e legitimistas enfrentam-se "como representantes do mundo e da ordem burguesa, não como cavaleiros errantes de princesas longínquas" (18 Br., p. 465); e os interesses puramente políticos são reduzidos à sua essência, i. e., aos interesses especificamente econômicos.

Todavia, note que "reduzidos" não significa dissolvidos. Aqui cabem duas observações.

Esse procedimento analítico é análogo à intenção crítica que caracteriza a "crítica da Economia Política" (n'O capital) e a crítica da Filosofia Especulativa (em A sagrada família, por exemplo). A “crítica da prática política", para mantermos a similitude, é igualmente desmistificadora, ainda que a desmistificação não corrija a realidade tal como os homens a representem (simbolicamente) e a percebam (ideologicamente). Achamos portanto aqui o problema da eficácia própria das representações coletivas - de fato, o primeiro tema d'O 18 Brumário de Luís Bonaparte, como lembrou Antoine Artous ${ }^{55}$. 
O método empregado no trabalho - traduzido na linguagem que o acompanha - obriga o analista a reconhecer a influência das justificações ideológicas sobre os interesses econômicos, das representações imaginárias sobre o "mundo profano" (18 Br., p. 453). Não é precisamente por essa idéia - a eficácia simbólica do político e a eficácia política do simbólico - que começa o livro?

Quando os homens parecem empenhados em transformar-se a si mesmos e a revolucionar as coisas, em criar o absolutamente novo, é justamente nesses períodos de crise revolucionária que evocam ansiosamente em seu auxílio os espíritos do passado, tomando-lhes emprestado os nomes, as suas palavras de ordem e vestimentas, a fim de representar a nova peça histórica sob um antigo e venerável disfarce e com essa linguagem emprestada" (18 Br., p. 437-438).

Marx lembra que "Lutero adotou a máscara do apóstolo Paulo, [..] a Revolução de 1789-1814 disfarçou-se ora como República romana, ora como Império romano" (18 Br., p. 438) e que "um século antes Cromwell e o povo inglês haviam emprestado do Velho Testamento sua linguagem, suas paixões e suas ilusões para servir à sua revolução burguesa" (18 Br., p. 439). A escolha dos termos não é arbitrária: "máscara", "disfarce", "ilusão" querem sugerir que esse simbolismo é antes de tudo uma ideologia: "As revoluções [burguesas] tiveram de recorrer a recordações da história universal para se iludirem quanto ao seu próprio conteúdo" (18 Br., p. 440). Mas uma ideologia - ou uma "aparência" - que tem o poder de produzir um efeito determinado, empurrar a História para frente; uma fantasia (no duplo sentido: como imaginação e como disfarce) eficiente, não uma mistificação simplória. Na interpretação de Paul-Laurent Assoun, um imaginário coletivo que tem a propriedade de produzir a realidade. ${ }^{56}$

A segunda observação, que decorre da primeira, é menos óbvia, penso eu: é exatamente nesse terreno ideológico que se dão as práticas políticas de classe, pois não há um outro lugar possível. Essa é uma idéia indicada, de passagem, no próprio "Prefácio" de 1859. Recorde-se que, numa 
“época de revolução social”, é por meio das "formas jurídicas, políticas, religiosas, artísticas ou filosóficas, em resumo, [das] formas ideológicas [que] os homens tomam consciência desse conflito e o conduzem até o fim". 57

Assim, os gladiadores da sociedade burguesa

[...] encontraram nas austeras tradições clássicas da República romana os ideais e as formas de arte, as ilusões de que necessitavam para ocultarem de si próprios as limitações burguesas do conteúdo de suas lutas e manterem sua paixão à altura da grande tragédia histórica. (18 Br., p. 439).

Logo, a menos que sejamos reféns de uma fantasia objetivista, é preciso preterir a idéia, manifesta em A Ideologia Alemã, segundo a qual o "ideológico" é uma simples aparência passível de ser corrigida. Esse entendimento conduz a projetar sobre o par essência-aparência uma antinomia essencialista e abstrata do tipo verdadeiro-versus-falso em tudo estranha ao "espírito" do texto marxiano. Raymond Williams sublinhou a propósito desse problema que

a decisão de não partir 'daquilo que os homens dizem, imaginam, concebem, nem dos homens como narrados, pensados, imaginados, concebidos' será portanto, no máximo, um lembrete corretivo de que há outras evidências, e por vezes mais convincentes, daquilo que eles fizeram. Mas será também, em seus piores aspectos, uma fantasia objetivista: a de que todo o 'processo de vida real'pode ser conhecido independentemente da linguagem e de seus registros. ${ }^{58}$

Contra a "autonomia da política", das suas leis exclusivas e dos seus movimentos próprios, o recurso marxiano por excelência consiste em tecer o fio que liga as instituições (políticas) e as representações (ideológicas) à realidade "econômica", isto é, às "contradições da vida material". O livro de Marx é o cumprimento eficiente dessa tarefa desmistificadora por meio da sua linguagem conotativa. Mas não se pode des-

${ }^{57}$ K. Marx, op. cit., "Prefácio", p. 25.

58 Raymond Williams, 1979, p. 65, grifos meus. De acordo com Norman Geras, "as distinções forma/conteúdo, aparência/essência conservam sua significação para a análise e a explicação [das] realidades [sociais], com a condição de que não se tome o primeiro termo de cada uma das oposições como sinônimos de ilusão". V. Geras, 1977, p. 270. 
conhecer a função específica de mediação das instituições políticas e das representações ideológicas - as "formas" - no processo de dominação social do capitalismo. O duende que Engels menciona na carta a Bloch, afinal, não é apenas uma fantasmagoria. O que ele não tem é vontade própria.

ADRIANO NERVO CODATO é professor de Ciência Política na Universidade Federal do Paraná e coordenador do Núcleo de Pesquisa em Sociologia Política Brasileira da mesma Universidade.

\section{REFERÊNCIAS BIBLIOGRÁFICAS}

ALTHUSSER, Louis Posições I. Rio de Janeiro: Graal, 1978. Pour Marx. Paris: François Maspero, 1965.

ANDERSON, Perry. A crise da crise do marxismo: introdução a um debate contemporâneo. São Paulo: Brasiliense, 1984. Considerations on Western Marxism. London: New Left Books, 1976.

ARON, Raymond. As etapas do pensamento sociológico. 2a. ed. São Paulo: Martins Fontes/Editora Universidade de Brasília, 1987.

ARONOWITZ, Stanley e BRATSIS, Peter (eds.). Paradigm Lost. State Theory Reconsidered. Minneapolis: University of Minnesota Press, 2002.

ARTOUS, Antoine. Marx, l'État et la politique. Paris: Syllepse, 1999.

BLOCK, Fred. Beyond Relative Autonomy: State Managers as Historical Subjetcs. In: Revising State Theory. Essays in Politics and Postindustrialism. Philadelphia: Temple University Press, 1987.

CARVER, Terrell. Imagery/Writing, Imagination/Politics: Reading Marx through the Eighteenth Brumaire. In: James Martin \& Mark Cowling (eds.), Marx's Eighteenth Brumaire: (Post)Modern Interpretations. London: Pluto Press, 2002. Marx's Social Theory. Oxford: Oxford University Press, 1983.

COLLIOT-THÉLÈNE, Catherine. Le materialisme historique a aussi une histoire. Actes de la recherche en Sciences Sociales, Paris, n. 55, novembre 1984, p. 15-21.

EAGLETON, Terry. Ideologia. Uma introdução. São Paulo: Editora da Universidade Estadual Paulista; Editora Boitempo, 1997. After Theory, London: Allen Lane/Penguin Press, 2003. As ilusões do pós-modernismo. Rio de Janeiro: Jorge Zahar Ed., 1998.

ENGELS, Friedrich. Carta de F. Engels a Bloch, 21-22 set. 1890, In: Karl Marx e Friedrich Engels, Obras Escolhidas. São Paulo: Alfa-Ômega, vol. 3, s/d. Carta de F. Engels a Schmidt, 27 out. 1890. In: Karl Marx e Friedrich Engels, Obras Escolhidas. São Paulo: Alfa-Ômega, vol. 3, s/d. Carta de F. Engels a Starkenburg, 25 jan. 1894. In: Karl Marx e Friedrich Engels, Obras Escolhidas. São Paulo: Alfa-Ômega, vol. 3, s/d. Introdução de Friedrich Engels à edição de 1895. In: Karl Marx, As lutas de classe em França de 1848 a 1850. Lisboa/Moscou: Avante!;Progresso, 1982. Prefácio de Engels para a terceira edição alemã [1885]. In: Karl Marx, O 18 Brumá rio de Luís Bonaparte. $2^{\mathrm{a}}$ ed. São Paulo: Abril Cultural, 1978, Col. Os Pensadores.

GERAS, Norman. Essência e aparência: aspectos da análise da mercadoria em Marx. In: Gabriel Cohn (org.). Sociologia: para ler os clássicos. Rio de Janeiro: Livros Técnicos e Científicos, 1977. 
Post-Marxism? New Left Review, London, n. 163, May-June 1987, p. 40-84.

GIDDENS, Anthony. Capitalismo e moderna teoria social. 2a. ed. Lisboa: Editorial Presença, 1984.

HOBSBAWM, Eric. O que os historiadores devem a Karl Marx? In: Sobre história. São Paulo: Companhia das Letras, 1998.

JESSOP, Bob. State Theory: Putting Capitalist State in its Place. Pennsylvania: The Pennsylvania University Press, 1990.

LACAPRA, Dominick. Reading Marx: The Case of The Eighteenth Brumaire. In: Rethinking Intellectual History: Texts, Contexts, Language. Ithaca and London: Cornell University Press, 1987.

LEFORT, Claude. A revolução enquanto princípio e enquanto indivíduo. In: . Pensando o político: ensaios sobre democracia, revolução e liberdade. Rio de Janeiro: Paz e Terra, 1991.

LEFORT, Claude. Marx: de uma visão de história a outra. In: As formas da História. Ensaios de Antropologia Política. 2a. ed. São Paulo: Brasiliense, 1990. Releitura do Manifesto Comunista. In: . Pensando o político: ensaios sobre democracia, revolução e liberdade. Rio de Janeiro: Paz e Terra, 1991.

LUPORINI, Cesare. Le Politique et l'Étatique: une ou deux critiques? In: Étienne Balibar, Cesare luporini, André Tosel. Marx e sa critique de la politique. Paris: Maspero, 1979.

MARTIN, James. Performing Politics: Class, ideology and Discourse in Marx's Eighteenth Brumaire. In: James Martin \& Mark Cowling (eds.), Marx's Eighteenth Brumaire: (Post)Modern Interpretations. London: Pluto Press, 2002.

MARX, Karl e ENGELS, Friedrich. L'idéologie allemande. In: Karl Marx. Euvres. Trad.: Maximilien Rubel. Paris: Gallimard, 1982, Vol. III: Philosophie. Bibliothèque de La Pléiade.

MARX, Karl. O 18 Brumário e cartas a Kugelman. $7^{\mathrm{a}}$. ed. Rio de Janeiro: Paz e Terra, 2002. A guerra civil na França. In: Karl Marx e Friedrich Engels, Obras Escolhidas. São Paulo: Alfa-Ômega, vol. 2. s/d.

Le 18 Brumaire de Louis Bonaparte. In: __. Euvres. Trad.: Maximilien Rubel. Paris: Gallimard. Vol. IV, Tomo I: Politique. Bibliothèque de La Plêiade, 1994.

MARX, Karl. Para a crítica da Economia Política. São Paulo: Abril Cultural, 1982.

MEHLMAN, Jeffrey. Revolution and Repetition: Marx-Hugo-Balzac. Berkeley and Los Angeles: University of California Press, 1978.

MÉSZÁROS, István. Marx's Theory of Alienation. London: Merlin Press, 1979.

PANITCH, Leo. The Impoverishment of State Theory. In: Stanley Aronowitz y Peter Bratsis, (eds.). Paradigm Lost. State Theory Reconsidered. Minneapolis: University of Minnesota Press, 2002.

POULANTZAS, Nicos. Pouvoir politique et classes sociales. Paris: Maspero, 1968.

ROSE, Margaret A. The Holy Cloak of Criticism: Structuralism and Marx's Eighteenth Brumaire. Thesis Eleven, v. 2, 1981, p. 79-97.

RUBEL, Maximilien. Karl Marx devant le bonapartisme. Paris: Mouton \& CO, 1960.

SKOCPOL, Theda. Bringing the State Back In: Strategies of Analysis in Current Research. In: Peter B. Evans; Dietrich Rueschemeyer; Theda Skocpol. Bringing the State Back In. Cambridge: Cambridge University Press, 1985.

SPENCER, Martin E. Marx on the State: The Events in France between 1848-1850. Theory and Society, v. 7, Jan.-May, 1979, p. 167-198.

THERBORN, Göran. A análise de classe no mundo atual: o marxismo como ciência social. In: Eric Hobsbawm (org.). História do marxismo. Rio de Janeiro: Paz e Terra, 1989, Col. História do marxismo, v. 11.

THOMPSON, E. P. As peculiaridades dos ingleses. In: Antonio Luigi Negro e Sergio Silva (orgs.). As peculiaridades dos ingleses e outros artigos. Campinas: Editora da Unicamp, 2001. 
WILLIAMS, Raymond. Marxismo e literatura. Rio de Janeiro: Zahar, 1979.

WOLFF, Jonathan. The 18th Brumaire and the 1859 Preface (Pre-conference draft). Paper presented 150th Anniversary of the Publication of The Eighteenth Brumaire of Louis Bonaparte at the Murphy Institute of Political Economy. Tulane University. New Orleans, Louisiana, USA, 13th-14th April. 2002. 


\section{RESUMOS/ABSTRACTS}

\section{O DEZOITO BRUMÁRIO, POLÍTICA E PÓS-MODERNISMO}

\section{ADRIANO NERVO CODATO}

A maioria das interpretações contemporâneas das análises de Karl Marx sobre a política européia da segunda metade do século XIX têm, em comum, a supressão de toda menção à "economia" e sua substituição, ou pela autonomia da política, nas versões heterodoxas, ou pelo caráter performativo da linguagem, nas versões pós-modernas. Neste artigo, sustenta-se que há n'O 18 Brumário de Luís Bonaparte uma interpretação da política que pode ser reduzida, do ponto de vista teórico, a dois princípios explicativos da concepção materialista da história: a primazia do econômico e a oposição entre essência e aparência. $\mathrm{O}$ artigo se propõe a verificar a incidência desses postulados naquele texto.

Palavras-chave: Karl Marx; O Dezoito Brumário de Luís Bona parte; Materialismo Histórico; Pós-Modernismo.

\section{THE EIGHTEENTH BRUMAIRE, POLITICS AND POSTMODERNISM}

Most contemporary interpretations of Karl Marx's analyses of European politics of the second half of the nineteenth century share both the suppression of all references to the "economy" and its substitution either for the idea of the autonomy of the political (in heterodox views), or for the idea of the performative aspect of language (in post-modern views). This article argues that Marx's Eighteenth Brumaire of Louis Bonapart contains an interpretation of politics that can be reduced, from the theoretical point of view, to two explanatory principles of the materialist conception of history: the primacy of economics, and the opposition between essence and appearance. The article seeks to verify the incidence of these two fundamental propositions within that text.

Keywords: Karl Marx; The Eighteenth Brumaire of Louis Bonaparte; Historical Materialism; Postmodernism. 